\title{
LONG-TERM BIOMONITORING OF SOIL CONTAMINATION USING POPLAR TREES: ACCUMULATION OF TRACE ELEMENTS IN LEAVES AND FRUITS
}

\author{
P. Madejón, L. Ciadamidaro, T. Marañón, and J. M. Murillo \\ Instituto de Recursos Naturales y Agrobiología, IRNAS, CSIC, Seville, Spain
}

Phytostabilization aims to immobilize soil contaminants using higher plants. The accumulation of trace elements in Populus alba leaves was monitored for 12 years after a mine spill. Concentrations of $A s$ and Pb significantly decreased, while concentrations of $C d$ and $\mathrm{Zn}$ did not significantly over time. Soil concentrations extracted by $\mathrm{CaCl}_{2}$ were measured by ICP-OES and results of $\mathrm{As}$ and $\mathrm{Pb}$ were below the detection limit. Long-term biomonitoring of soil contamination using poplar leaves was proven to be better suited for the study of trace elements. Plants suitable for phytostabilization must also be able to survive and reproduce in contaminated soils. Concentrations of trace elements were also measured in $P$. alba fruiting catkins to determine the effect on its reproduction potential. Cadmium and $\mathrm{Zn}$ were found to accumulate in fruiting catkins, with the transfer coefficient for Cd significantly greater than Zn. It is possible for trace elements to translocate to seed, which presents a concern for seed germination, establishment and colonization. We conclude that white poplar is a suitable tree for long-term monitoring of soil contaminated with $\mathrm{Cd}$ and $\mathrm{Zn}$, and for phytostabilization in riparian habitats, although some caution should be taken with the possible effects on the food web.

Supplemental materials are available for this article. Go to the publisher's online edition of International Journal of Phytoremediation to view the supplemental file.

KEY WORDS: Salicaceae, trace elements, bioindicators, Populus alba, Guadiamar, phytostabilization

\section{INTRODUCTION}

Phytostabilization is a remediation technique that uses plants to immobilize soil contaminants. The establishment of a vegetation cover is undoubtedly the most useful and widespread method of physically stabilizing mine wastes and reducing metal pollution effects (Bargagli 1998). A vegetative cover plays a vital role in stabilization by reducing the water flux through soil profile and mechanically stabilizing the soil through root growth, while also reducing the movement of soil and the associated contaminants. Poplar trees, as well as deep-rooted plants with high transpiration rates, can effectively decrease the migration of contaminants from surface water into groundwater (Bolan et al. 2011). In addition, poplars (and other trees belonging to the Salicaceae family) are well-known 
by their ability to accumulate $\mathrm{Cd}$ and $\mathrm{Zn}$ in their leaves, making them suitable for the phytoextraction of these elements from contaminated sites (Robinson et al. 2000), and also as biomonitors of soil contamination (Madejón et al. 2004, 2006).

In phytostabilization, biomarkers are plants that provide information concerning the environmental quality at a contaminated site (Market et al., 2003). Long term soil contamination may be assessed by using plants as biomonitors, especially in areas where sampling and chemical analysis of soil samples may be challenging and expensive (Madejón et al. 2006; Bone et al. 2010). The use of trees as biomarkers is an inexpensive and efficient way to assess trace element bioavailability (Madejón et al. 2006; Bone et al. 2010).

Plants suitable for phytostabilization must be able to survive and reproduce in contaminated soils (Bolan et al. 2011). In many plants, physiological barriers impede the translocation of metals to seeds during their maturation (Ernst, Verkleij, and Schat 1992). For example, seeds from sunflower plants growing in contaminated soil had a lower concentration of Arsenic (As) and a lower concentration of lead $(\mathrm{Pb})$ than the blades of the same plant (Madejón et al. 2003). Poplar trees have the ability to accumulate high levels of $\mathrm{Cd}$ and $\mathrm{Zn}$ in their leaves (Robinson et al. 2000; Madejón et al. 2004; Lepp and Madejón 2007) and it is unknown whether these contaminants will also be transferred to the plants' fruits and seeds.

In a previous study (Madejón et al. 2004), the leaves of Populus alba L. were used as biomonitors of the extent of $\mathrm{Cd}$ and $\mathrm{Zn}$ soil contamination after a mine spill in the Guadiamar basin. Thirteen years after the spill and the phytoremediation of the area, $\mathrm{Cd}$ still persists at worrying concentrations (Domínguez et al. 2008; Madejón, Domínguez, and Murillo 2012). In order to determine future management and remediation actions it is necessary to determine the bioavailability of $\mathrm{Cd}$, and of trace elements in general, to the plants chosen for phytoremediation (Chapman 2012). Therefore this study was conducted at the same spill site as reported by Madejón et al. (2004).

The main objectives of this study were to evaluate the use of Populus alba as a biomonitor and to determine its potential to phytostabilize soil containing potential toxic trace elements $(\mathrm{Cd}, \mathrm{Zn}, \mathrm{As}$, and $\mathrm{Pb})$. In order to determine the ability of $P$. alba to phytoextract trace elements, the bioavailability of trace elements to the leaves of $P$. alba was assessed over 12 years. In addition, the concentration of trace elements in fruiting catkins of $P$. alba was determined to assess the potential effects that trace element contaminated soil has on reproduction.

\section{MATERIAL AND METHODS}

\section{Site and Species Study}

In 1998, the Aznalcóllar mine spill contaminated approximately $55 \mathrm{~km}^{2}$ of the Guadiamar valley with trace elements ( $\mathrm{As}, \mathrm{Cd}, \mathrm{Cu}, \mathrm{Pb}, \mathrm{Tl}$, and $\mathrm{Zn}$ ) (Cabrera et al. 1999). This area was subjected to a large-scale phytomanagement project, including clean up of sludge and topsoil, addition of soil amendments, and plantation of native shrubs and trees, and consequently protected as the "Guadiamar Green Corridor" (CMA 2003; Domínguez et al. 2008).

The climate of the studied zone is typically Mediterranean, with mild rainy winters (about $500 \mathrm{~mm}$ mean annual rainfall, Domínguez et al. 2008) and very hot and dry summers, with maximum values of solar radiation exceeding $1000 \mathrm{Wm}^{-2}$. The mean annual daily temperature is approximately $17^{\circ} \mathrm{C}$, with a maximum temperature of $33.5^{\circ} \mathrm{C}$ in July and a minimum temperature of $5.2^{\circ} \mathrm{C}$ in January. The predominant soils in the area belong to the great groups: Xerofluvent, Xerochrept, Haploxeralf and Rhodoxeralf (Cabrera et al. 2005). 
White poplar (Populus alba L.) is a common species in the riparian forest of the Guadiamar River, and it has been widely planted in the spill-affected area, which mostly consists of former agricultural lands (Madejón et al. 2004). In general, poplar species are suitable for phytoremediation because they are relatively tolerant to soil contamination, grow fast and have deep roots (Robinson et al. 2000, 2007; Bolan et al. 2011).

Sampling strategy. In a previous experiment, samples of Populus alba leaves were collected from five contaminated sites of the Guadiamar valley in 1999 (Madejón et al. 2004). Two sites: Aznalcázar (AZ, $37^{\circ} 18^{\prime} 12^{\prime \prime}, \mathrm{N}^{\circ} 15^{\prime} 38^{\prime \prime} \mathrm{W}$ ) and Doblas (DO, $37^{\circ}$ $\left.23^{\prime} 45^{\prime \prime} \mathrm{N}, 6^{\circ} 13^{\prime} 35^{\prime \prime} \mathrm{W}\right)$ were selected for additional leaf sampling. In October of 2000, 2001, 2005, and 2010, poplar leaves were taken from five trees per site. Using a spiral auger (2.5 cm diameter), soil samples were taken from the root-zone of each tree, about $2 \mathrm{~m}$ from the trunk, and at two depths $(0-20$ and $20-40 \mathrm{~cm})$. At each tree, three soil subsamples were collected at each depth.

In the spring of 2011, fruiting catkins and leaves were also collected from five trees at each site (AZ and DO). For comparison, fruiting catkins and leaves were also collected from an uncontaminated site, Rivera de Huelva (RHU, $37^{\circ} 29^{\prime} 4.8^{\prime \prime} \mathrm{N}, 6^{\circ} 01^{\prime} 34.0^{\prime \prime} \mathrm{W}$ ).

\section{Plant and Soil Analysis}

Plant material was partitioned for analysis into leaves and reproductive structures (for spring 2011 samples). Additionally, catkins were separated into green capsules (fruits) and the central stem or rachis. Samples were washed twice with distilled water for approximately 10 seconds, dried at $70^{\circ} \mathrm{C}$ for at least $48 \mathrm{~h}$, and ground by using a stainless-steel mill. Trace elements ( $\mathrm{As}, \mathrm{Cd}, \mathrm{Cu}, \mathrm{Fe}, \mathrm{Mn}, \mathrm{Ni}, \mathrm{Pb}$, and $\mathrm{Zn}$ ) and nutrients ( $\mathrm{Ca}, \mathrm{K}, \mathrm{Mg}, \mathrm{N}, \mathrm{P}$ y $\mathrm{S}$ ) were determined by wet oxidation with concentrated $\mathrm{HNO}_{3}$ under pressure in a microwave digester. The analysis of trace metals in the digests was performed by ICP-MS (inductively coupled plasma-mass spectroscopy). Analysis of mineral nutrients in the extracts was performed by ICP-OES (inductively coupled plasma spectrophotometry). The accuracy of the analytical method was determined using two plant reference materials: CRM 279 (sea lettuce) and NCS DS 73348 (poplar leaves) (Madejón et al. 2004). Recovery rates for reference plant samples were between 90 and $110 \%$.

Soil samples were oven-dried at $40^{\circ} \mathrm{C}$, for at least $48 \mathrm{~h}$, and crushed to pass a $2 \mathrm{~mm}$ sieve, and then ground to $<60 \mathrm{~mm}$ for trace element analysis. Total content of trace elements was determined by ICP-OES, after digesting the samples with a mixture of concentrated $\mathrm{HNO}_{3}$ and $\mathrm{HCl}$ ('aqua regia'). Available trace element in soils (in the soil fraction $<2 \mathrm{~mm}$ ) was determined by an extraction with $0.01 \mathrm{M} \mathrm{CaCl}_{2}$ in a relation 1 (soil sample) /10 (0.01 M $\mathrm{CaCl}_{2}$ extracts) after shaking for $3 \mathrm{~h}$ (Houba et al., 1996) and analyzed via ICP-OES.

The transfer coefficient (TC) is defined as the ratio of metal concentration in the plant to the total metal concentration in the soil (Adriano 2001). The TC was calculated in order to determine the concentration of trace elements that was transferred from the soil to aboveground plant tissue. In this study we calculated TC for leaves and for fruits separately using soil concentrations obtained from soil sampled at depth 0-20 cm.

\section{Statistical Analyses}

The temporal variation of the concentration of elements in poplar leaves was analyzed by ANOVA, based upon the year sampled and the site location. For the 2011 plant samples, site locations and plant fractions were used as fixed factors in the ANOVA analysis. When necessary, complementary analysis of the T-student test for paired means was carried out. 
Normality of the data was tested prior to analysis. Significant differences of all variables between the different years, sites and plant fractions were established by post-hoc Tukey's test. Correlation analyses for each element between the different fractions were calculated. The significance levels reported are based on Pearson coefficients.

To investigate the global pollution trends among sites and years, a principal component analysis (PCA) was performed using the concentration of eight trace elements (As, $\mathrm{Cd}, \mathrm{Cu}, \mathrm{Fe}, \mathrm{Mn}, \mathrm{Ni}, \mathrm{Pb}, \mathrm{Zn}$ ) in the leaves of 10 poplar trees over 5 sampling years (total of 50 cases). Previously, variables were transformed by square root to obtain a normal distribution. All statistical analyses were carried out with the program SPSS 15.0 for Windows.

\section{RESULTS}

\section{Monitoring long-term evolution of trace elements using poplar leaves}

Temporal patterns of trace elements in poplar trees are shown in Figure 1 and Table $\mathrm{S} 1$. The less mobile elements, $\mathrm{As}$ and $\mathrm{Pb}$ behaved differently than $\mathrm{Cd}$ and $\mathrm{Zn}$. From 1999-2010, As progressively and significantly reduced its leaf concentration from $3.05 \mathrm{mg}$
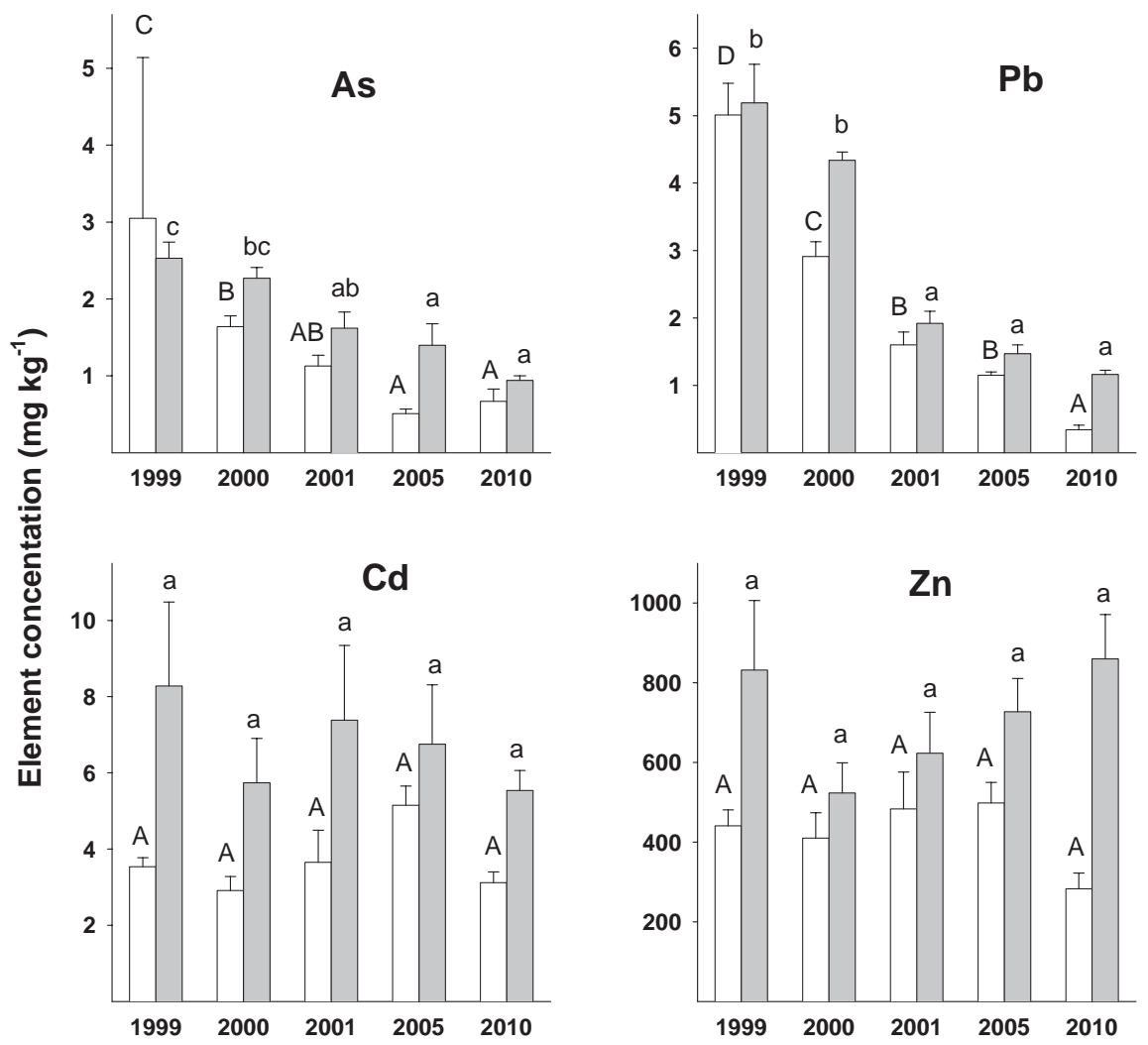

Figure 1 Temporal variation in trace element ( $\mathrm{As}, \mathrm{Pb}, \mathrm{Cd}$, and $\mathrm{Zn}$ ) concentrations in leaves of Populus alba $\mathrm{L}$. at two sites: 'Aznalcázar' (AZ, white columns) and 'Doblas' (DO, grey columns), during the period 1999-2010 (autumn samplings). For each element and site bars with the same letter do not differ significantly $(\mathrm{p}<0.05)$. Mean values \pm standard errors are expressed as $\mathrm{mg} \mathrm{kg}^{-1}$ of dry matter. 
Table 1 Extractable (by $\mathrm{CaCl}_{2}$ ) concentrations (mean value \pm standard error; $\mathrm{mg} \mathrm{kg}^{-1}$ ) of trace elements in the two studied soils at depth $0-20$ and $20-40 \mathrm{~cm}$.

\begin{tabular}{llrllll}
\hline Year & Soil & Depth & As & Cd & Pb & Zn \\
\hline 1999 & AZ & $0-20$ & <DL & $0.01 \pm 0.002$ & $<$ DL & $3.00 \pm 0.99$ \\
& & $20-40$ & $<$ DL & $0.03 \pm 0.009$ & $<$ DL & $0.95 \pm 0.41$ \\
& DO & $0-20$ & <DL & $0.24 \pm 0.10$ & $<$ DL & $49.8 \pm 20.4$ \\
& & $20-40$ & $<$ DL & $0.29 \pm 0.10$ & $<$ DL & $55.1 \pm 22.7$ \\
2010 & AZ & $0-20$ & $<$ DL & $0.01 \pm 0.002$ & $<$ DL & $0.20 \pm 0.08$ \\
& & $20-40$ & $<$ DL & $0.01 \pm 0.002$ & $<$ DL & $0.10 \pm 0.01$ \\
& DO & $0-20$ & $<$ DL & $0.51 \pm 0.22$ & $0.25 \pm 0.09$ & $79.0 \pm 35.0$ \\
& $20-40$ & $<$ DL & $0.48 \pm 0.16$ & $0.14 \pm 0.03$ & $65.7 \pm 21.1$ \\
\hline
\end{tabular}

DL: detection limit

$\mathrm{kg}^{-1}$ to $0.66 \mathrm{mg} \mathrm{kg}^{-1}$ at site $\mathrm{AZ}$ and from $2.53 \mathrm{mg} \mathrm{kg}^{-1}$ to $0.95 \mathrm{mg} \mathrm{kg}^{-1}$ at site DO. Similarly $\mathrm{Pb}$ values decreased from $5.00 \mathrm{mg} \mathrm{kg}{ }^{-1}$ to $0.33 \mathrm{mg} \mathrm{kg}^{-1}$ in $\mathrm{AZ}$ and from $5.19 \mathrm{mg} \mathrm{kg}^{-1}$ to $1.15 \mathrm{mg} \mathrm{kg}^{-1}$ at site DO. However, $\mathrm{Cd}$ and $\mathrm{Zn}$ concentrations remained comparatively high and did not differ significantly over time (Table S2). Concentrations of $\mathrm{Cd}$ and $\mathrm{Zn}$ at site $\mathrm{AZ}$ were significantly different from $\mathrm{Cd}$ and $\mathrm{Zn}$ concentrations at site DO.

Previously, Madejón et al. (2004) reported that soil at both sites (AZ and DO) in 1999 had a neutral $\mathrm{pH}$, and trace element concentrations (extracted by 'aqua regia') of approximately $111 \mathrm{mg} \mathrm{kg}^{-1}$ of As, $4 \mathrm{mg} \mathrm{kg}^{-1}$ of $\mathrm{Cd}, 305 \mathrm{mg} \mathrm{kg}^{-1}$ of $\mathrm{Pb}$ and $583 \mathrm{mg} \mathrm{kg}^{-1}$ $\mathrm{Zn}$.

Available contents of $\mathrm{As}$ and $\mathrm{Pb}$ in soils $\left(0.01 \mathrm{M} \mathrm{CaCl}_{2}\right.$ extraction) were below the detection limit, with exception of $2010 \mathrm{~Pb}$ samples at DO site (Table 1). The measurable concentrations of $\mathrm{Cd}$ and $\mathrm{Zn}$ did not show a definite temporal trend with respect to the year sampled and the site location. Although, soil samples analyzed for $\mathrm{Zn}$ at site $\mathrm{AZ}$ were significantly different between years.

Figure 2 shows the pollution multivariate trends in poplar leaves during the 12 years of study. The first PCA axis explained $33.7 \%$ of the variance and was associated with a global trend of five elements $(\mathrm{Pb}, \mathrm{As}, \mathrm{Fe}, \mathrm{Cd}$, and $\mathrm{Zn}$ ), while the second PCA axis, with $30.7 \%$ of the variance, separated $\mathrm{Pb}$, As and $\mathrm{Fe}$ (negative scores) from $\mathrm{Cd}$ and $\mathrm{Zn}$ (positive scores). The evolution of trace elements in poplar leaves with time was represented by the changes in the PCA-space location of mean values per site in each of the five sampling years. In general, samples of both sites moved towards PCA coordinates indicating lower concentrations of $\mathrm{Pb}$ and $\mathrm{As}$ (negative scores of axis 1), $\mathrm{Cd}$ and $\mathrm{Zn}$. However, with respect to the second PCA axis, samples of the two sites diverged with time. Soil samples from the $\mathrm{DO}$ site increased in $\mathrm{Zn}$ and $\mathrm{Mn}$ (positive scores of axis 2) while those from the $\mathrm{AZ}$ site remained similar with time.

The transfer coefficients (TCs) between the soil and P. alba followed similar temporal trends as leaf concentrations. A significant $(\mathrm{p}<0.05)$ decreasing TC trend for $\mathrm{As}$ and $\mathrm{Pb}$ was observed, while the TC trend for $\mathrm{Cd}$ and $\mathrm{Zn}$ did not significantly differ with time. Transfer coefficients for Cd were significantly higher than TCs for Zn at site DO in 1999 and at site $\mathrm{AZ}$ in 2010. The transfer coefficients for $\mathrm{Cd}$ and $\mathrm{Zn}$ were both much higher than those of $\mathrm{As}$ and $\mathrm{Pb}$ (Figure 3). These results suggest that $\mathrm{Cd}$ and $\mathrm{Zn}$ are translocated into $P$. $a l b a$ at a higher rate than $\mathrm{As}$ and $\mathrm{Pb}$. 


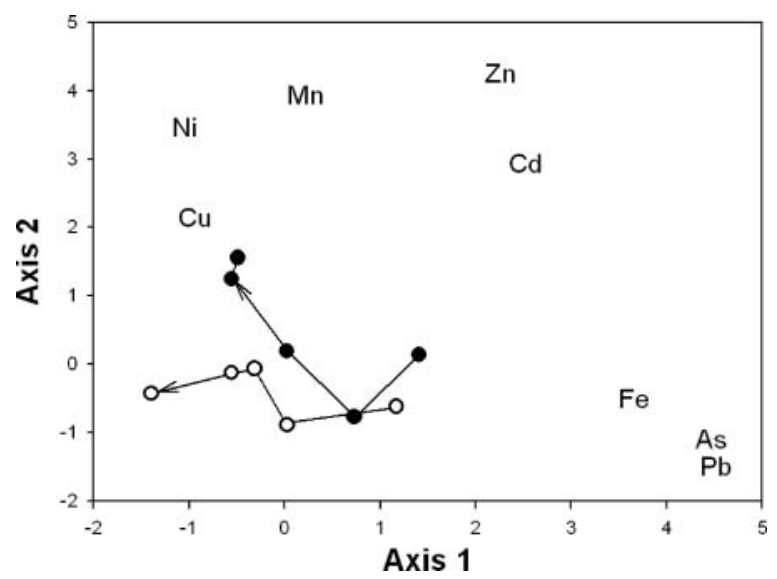

Figure 2 Ordination of poplar leaf samples by the two first axes of principal component analysis (PCA), according to their concentration of eight trace elements. Each circle represents the mean value for several trees in a single year sampling; in black for Doblas site and in white for Aznalcázar site. Arrows indicate the temporal trend direction from 1999 to 2010 samples. Scores of the elements in the PCA space have been multiplied by five, for clarity.

\section{Allocation of Trace Elements and Nutrients in Poplar Leaves and Fruits}

Concentrations of $\mathrm{As}$ and $\mathrm{Pb}$ in all poplar fractions were extremely low $(<0.1-0.3 \mathrm{mg}$ $\mathrm{kg}^{-1}$; Figure 4) compared to concentrations measured in autumn leaves (approximately $1 \mathrm{mg} \mathrm{kg}^{-1}$, Figure 1), which had the largest concentration of As and $\mathrm{Pb}$. In poplar fruits, the accumulation of $\mathrm{As}$ and $\mathrm{Pb}$ from contaminated soils was not significantly different from the non-contaminated site (RHU) $(p<0.23)$, despite the significant differences in leaf concentration $(\mathrm{p}<0.05, \mathrm{AZ})$. The ANOVA tests for As and $\mathrm{Pb}$ did not show significant differences between plant organs and sites (Table S3).

In spring 2011, a consistent accumulation of $\mathrm{Cd}$ and $\mathrm{Zn}$ was measured in the catkin stems and fruits (green capsules). Maximum concentrations of $\mathrm{Cd}$ and $\mathrm{Zn}$ in catkin stems were $3.5 \mathrm{mg} \mathrm{kg}^{-1}$ and $360 \mathrm{mg} \mathrm{kg}^{-1}$, respectively at DO site (Figure 4). Within the catkins,
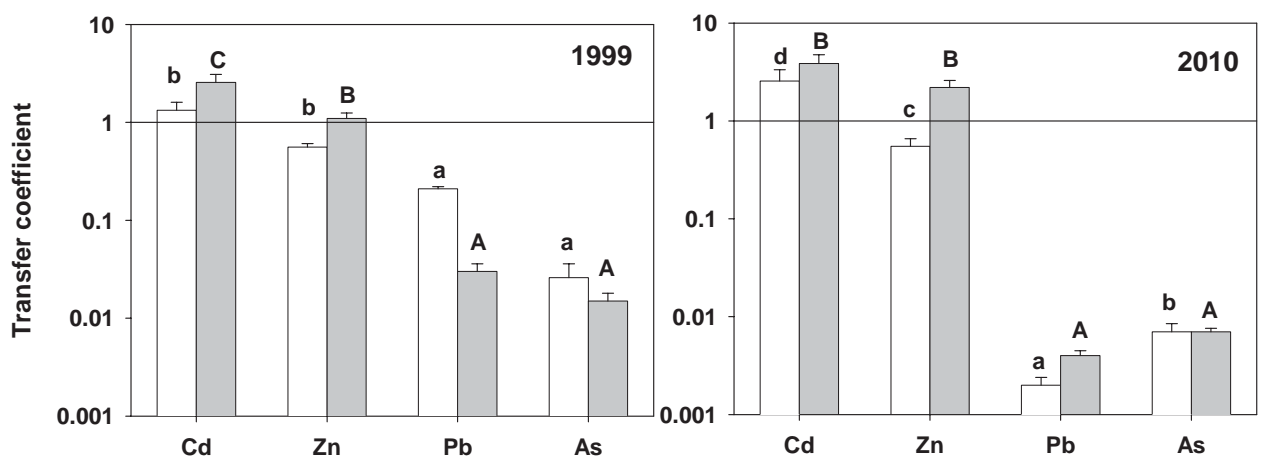

Figure 3 Transfer coefficients (in 1999 and 2010), defined as element concentration in leaves divided by the total element concentration in soils (at 0-20 cm depth) in AZ site (white bars) and DO site (grey bars) for poplar leaves. Mean values \pm standard error, expressed in log scale. For each year and site bars with the same letter do not differ significantly ( $\mathrm{p}<0.05$ ). 


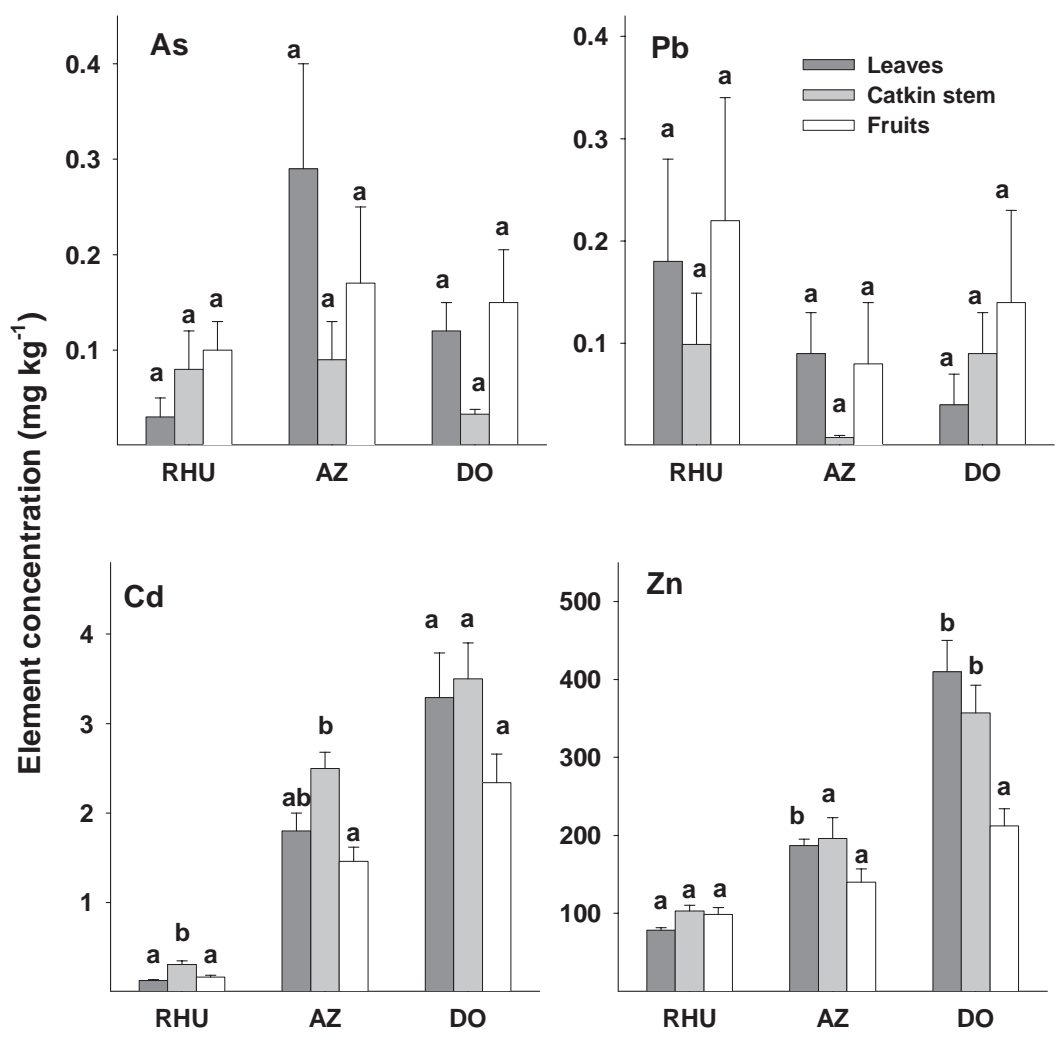

Figure 4 Trace element concentration in different plant fractions of Populus alba L. (spring sampling 2011). For each site, bars (fractions) with the same letter do not differ significantly $(\mathrm{p}<0.05)$. Mean values \pm standard errors are expressed as $\mathrm{mg} \mathrm{kg}^{-1}$ of dry matter.

Cd concentrations were significantly lower in the fruits when compared to the stems at site $\mathrm{AZ}$ and $\mathrm{Zn}$ was significantly lower in the fruits than the stems at site DO (Figure 4). When comparing the three organs (leaves, catkin stems and fruits) significant correlations were found between concentrations of $\mathrm{Zn}$ and $\mathrm{Cd}(\mathrm{r}=0.96 \mathrm{p}<0.001)$.

Nutrient concentrations from the leaves, catkin stems and fruits are shown in Figure 5. There were significant differences between sites and organs for Ca, K, P, and S (Table S3). The non-contaminated site (RHU) had significantly more nitrogen in $P$. alba fruits and leaves, significantly more $\mathrm{K}$ in the leaves, and significantly more $\mathrm{Ca}$ in the fruits.

During the spring 2011 sampling, the transfer coefficient for $\mathrm{Cd}$ from soil to fruits at RHU tended to be greater than from soil to leaves, with the opposite trend at the contaminated sites (Figure 6). In general, the TC values for $\mathrm{Cd}$ (1.5-2.5) were greater than those of $\mathrm{Zn}(0.5-1.5)$. In the case of $\mathrm{Zn}$, the TC values from soil to both leaves and fruits were higher at the uncontaminated site (RHU) than at the contaminated sites, AZ and DO (Figure 6).

\section{DISCUSSION}

The decreasing concentrations of $\mathrm{As}$ and $\mathrm{Pb}$, contrast the high, stable concentrations of $\mathrm{Cd}$ and $\mathrm{Zn}$ in poplar leaves. This confirms the need for long-term studies to monitor 

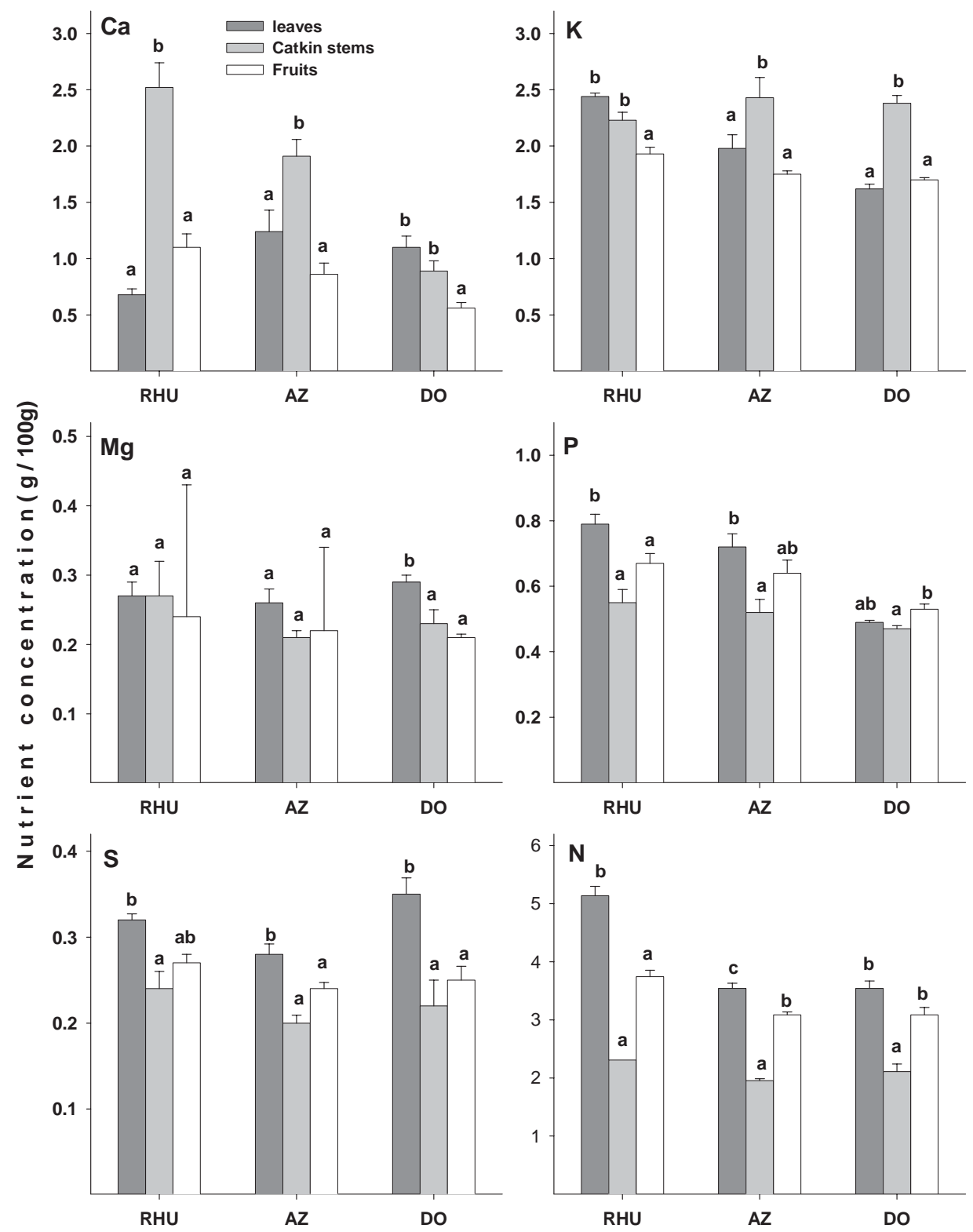

Figure 5 Differences in nutrients $(\mathrm{Ca}, \mathrm{K}, \mathrm{Mg}, \mathrm{N}, \mathrm{P}$, and $\mathrm{S})$ concentrations in the plant fractions (leaves, catkin stems and fruits) of Populus alba L. (spring sampling 2011). For each site, bars (fractions) with the same letter do not differ significantly $(\mathrm{p}<0.05)$. Mean values \pm standard errors are expressed as $\mathrm{g} / 100 \mathrm{~g}$ of dry matter.

the potential toxicity of residual contamination in the Guadiamar Valley. Moreover, leaf concentrations of $\mathrm{Cd}$ and $\mathrm{Zn}$ in the last sampling (12 years after the accident), were still much higher than normal values in higher plants $\left(0.02-0.5 \mathrm{mg} \mathrm{kg}^{-1}\right.$ for $\mathrm{Cd}$ and $27-150 \mathrm{mg}$ $\mathrm{kg}^{-1}$ for Zn; Kabata-Pendias and Pendias 1992). In general, long-term datasets are essential resources in ecological and environmental research (e.g., Reinds, Posch, and Vries 2009; Magurran et al. 2010). 

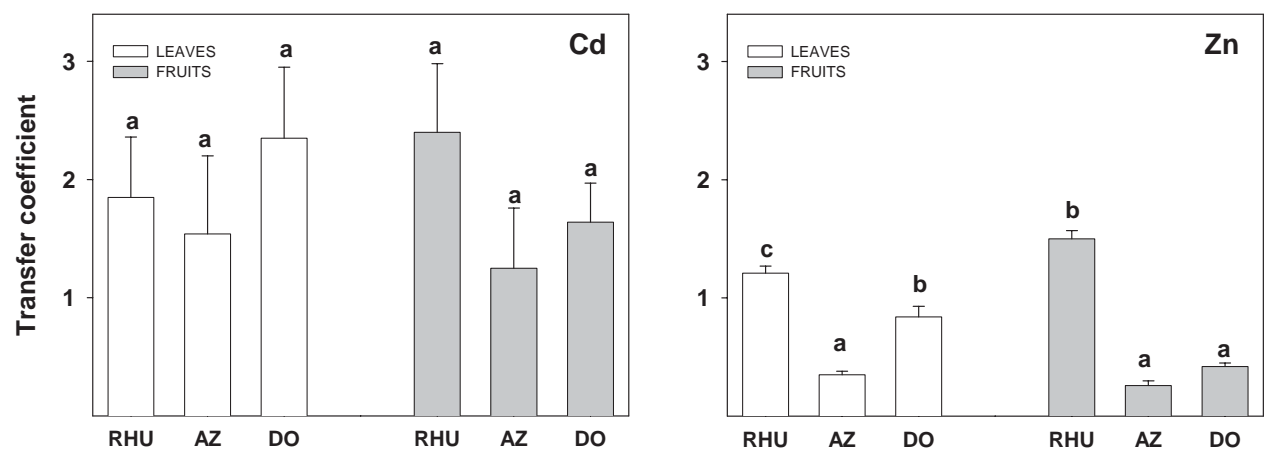

Figure 6 Transfer coefficients in poplar leaves (in white) and fruits (in grey) using soil depth 0-20 cm at the three studied sites; sampling in spring 2011. Mean values \pm standard error. For each fraction (leaves or fruits) bars with the same letter do not differ significantly $(\mathrm{p}<0.05)$.

The availability of mineral elements in soil can be best monitored by using the content actually uptaken and accumulated by plants (Madejón et al. 2006). Alternatively, phytoavailability can be estimated by chemical extracts that simulate root uptake (Menzies, Donn, and Kopittke 2007). Although, these are indirect methods that are empirically related to the bioavailability of the contaminates to the plants, a single universal soil test to accurately assess risks due to contamination of soils by heavy metals does not exist (McLaughlin et al. 2000; Xiao-Lan, Chen, and Shenker 2005).

In the case of trace elements, neutral salt extractants (such as $0.01 \mathrm{M} \mathrm{CaCl}_{2}$ ) are widely used and provide the most useful indication (Menzies, Donn, and Kopittke 2007). However this fraction is not easily measured, especially in the case of less mobile elements, such as $\mathrm{As}$ and $\mathrm{Pb}$ (Madejón et al. 2009). To cope with these difficulties, it is common to resort to stronger extractants such as EDTA, although results are not always convincing, as the availability of some trace elements may be overestimated (Vidal et al. 1999; McLaughlin et al. 2000; Madejón et al. 2006). In this study, the leaves of poplar detected a descending trend for $\mathrm{As}$ and $\mathrm{Pb} 12$ years after the mine spill. Even though the soil values were below detection limits, we could use poplar leaves as biomonitors to detect a gradual reduction in As and $\mathrm{Pb}$ contamination. Therefore, this study corroborates the suitability of poplar leaves to bioindicate soil quality (Madejón et al. 2006). This trend was also measured in transfer coefficients from soil to leaves, which decreased with time for As and $\mathrm{Pb}$, but did not vary significantly for the more mobile elements $\mathrm{Cd}$ and $\mathrm{Zn}$.

The multivariate analysis of the eight trace elements in poplar leaves during five sampling years indicated a main temporal gradient associated to the contamination of $\mathrm{Pb}$, As and Fe. This trend was similar to that described for spatial variation (five sites) in one single year, 1999 (Madejón et al. 2004). The contamination of poplar leaves decreased with time (moving towards the lower pollution region in the PCA space). A secondary trend of variation was site-dependent; concentrations of $\mathrm{Zn}$ and $\mathrm{Mn}$ in leaf samples increased with time at site DO and remained similar at site AZ.

Most metal localization studies in trees have focused on leaf and stem tissues, with few reporting on metal contents in fruits/seeds. In vascular plants, it is common to have physiological barriers impeding metal translocation to seeds during maturation. In the case of poplar, its ability to accumulate $\mathrm{Cd}$ and $\mathrm{Zn}$ in its leaves presents a risk to the reproductive structures. The transfer coefficients for $\mathrm{Cd}$ and $\mathrm{Zn}$ in the non-contaminated zone (RHU) 
were relatively high, suggesting that $\mathrm{Cd}$ and $\mathrm{Zn}$ are able to translocate to the reproductive structures. At the contaminated sites, the transfer coefficients for $\mathrm{Cd}$ were significantly greater than those of $\mathrm{Zn}$, indicating a greater mobility and translocation. Based on the toxicity of $\mathrm{Cd}$, this would represent a higher risk to reproductive structures (Kranner and Colville 2011). High concentration of $\mathrm{Cd}$ in embryonic or in reserve tissues would have deleterious consequences for seed germination, seedling establishment and colonization success (Kranner and Colville 2011). Despite this relative accumulation of $\mathrm{Cd}$ and $\mathrm{Zn}$ in green capsules, the poplar seeds may present a physiological barrier at the seed coat, which may protect the embryo from toxic effects (Ernst and Nelissen 2000; Bhatia et al. 2003). Further studies to assess the spatial trace element distribution into the seed are advisable; for example, by using micro-Proton-Induced X-ray Emission (Vogel-Mikuš et al. 2007).

In an independent study conducted at the same spill site, Domínguez et al. (2010b) showed that the altered soil condition (higher level of trace elements and lower $\mathrm{pH}$ ) originated by the mine-spill enhanced the uptake of several nutrients in afforested $P$. alba. Additionally, a similar 'fertilizing' effect was reported earlier by Murillo et al. (1999) on crops that were immediately affected by the mine-spill. In these studies, trace element contamination did not negatively affect mineral nutrition in the studied plants, a positive feature for phytoremediation. Values of macronutrients in leaves, catkin stems and fruits were similar when comparing contaminated and non-contaminated sites, with the exception of higher concentrations of $\mathrm{N}$ and $\mathrm{Ca}$ in fruits from the non-contaminated site. The nutrients measured in poplar leaves from contaminated sites, were comparable to reported levels for Populus species (Mills and Jones 1996): 2-3 for N, 0.37 for S, 0.2-2.6 for K, 0.15-0.4 for $\mathrm{P}, 1-2.3$ for $\mathrm{Ca}$ and $0.15-0.7$ for $\mathrm{Mg}$ (expressed in\%).

It is important that the plants chosen for phytostabilization can tolerate high concentrations of trace elements and nutrient imbalances (Bolan et al. 2011). In general, white poplar trees used in the phytomanagement of the Guadiamar valley showed high survival and growth rates, as well as adequate nutritional status (Domínguez et al. 2010a, b). According to the nutrients analysis, white poplar seem to overwhelm this adversity corroborating its suitability for phytostabilization. These results confirm the suitability of $P$. alba to phytoremediate and thus phytostabilize trace element contaminated soil.

The use of accumulator species in phytostabilization could provide an opportunity for trace elements to enter the food web (Domínguez et al. 2008; Bolan et al. 2011). White poplar could potentially cause an environmental problem with its ability to accumulate $\mathrm{Cd}$ and $\mathrm{Zn}$. However, there are several advantages supporting the use of white poplar in the phytostabilization of the Guadiamar valley. $P$. alba is the dominant native species in the riparian forests, it is also fast-growing, deep-rooted and tolerant to multiple stress conditions, and it has landscape and cultural values. Fast-growing trees, such as willow, poplar, alder and eucalyptus are commonly used to restore metal contaminated soils (Perttu 1993). Phytostabilization can also benefit carbon sequestration, watershed management, erosion, biomass production, while also improving the landscape for recreational activities (Dickinson et al. 2009; Marañón et al. 2012).

\section{CONCLUSIONS}

Phytostabilization of contaminated sites requires a monitoring program of trace elements. The results of this study confirmed the use of Populus alba as a long term biomonitor 
of trace elements in soil. Leaf concentrations of less mobile elements, As and $\mathrm{Pb}$, significantly decreased with time. In contrast, during the 12 years after the mine-spill, concentrations of $\mathrm{Cd}$ and $\mathrm{Zn}$ accumulated in leaf tissue. Plants suited for phytostabilization should be able to survive, grow and reproduce in contaminated conditions. Fruiting catkins of poplar (measured at the 12th year after the spill) had significant accumulation of $\mathrm{Cd}$ and $\mathrm{Zn}$, with possible deleterious consequences for seed germination, seedling establishment and colonization success. In general, the impaired soil conditions at the contaminated sites did not affect the nutritional health of poplar trees. There are advantages of using white poplar to phytostabilize trace metal contaminated soil at the Guadiamar Green Corridor, although more research is needed to understand the effects of trace metals on its reproductive ability and the potential for trace metals to enter food webs.

\section{ACKNOWLEDGMENTS}

This study was supported by AGL2008-00985, CGL2008-04503-C03-01 and CGL2011-30285-C02 projects, funded by the CICYT of the Spanish Ministerio de Ciencia e Innovación, and European FEDER funds. We thank two anonymous reviewers for their comments on an early version of the manuscript.

\section{REFERENCES}

Adriano DC. 2001. Trace elements in terrestrial environments: Biochemistry bioavailability and risks of metals. New York (NY): Springer-Verlag.

Bargagli R. 1998. Trace elements in terrestrial plants: An ecophysiological approach to biomonitoring and biorecovery. Berlin (Germany): Springer-Verlag.

Bhatia NP, Orlic, I, Siegele R, Ashwath N, Baker AJM, Walsh KB. 2003. Elemental mapping using PIXE shows the main pathway of nickel movement is principally symplastic within the fruit of the hyperaccumulator Stackhousia tryonii. New Phytol 160:479-488.

Bolan SN, Park JH, Robinson B, Naidu R, Huh KY. 2011. Phytostabilization: A Green approach to contaminant containment. Adv Agron 112:145-204.

Bone J, Head M, Barraclough D, Archer M, Scheib C, Flight D, Voulvoulis N. 2010. Soil quality assessment under emerging regulatory requirements. Environ Int 36:609-622.

Cabrera F, Clemente L, Díaz Barrientos E, López R, Murillo JM. 1999. Heavy metal pollution of soils affected by the Guadiamar toxic flood. Sci Total Environ 242:117-129.

Cabrera F, Clemente L, Cordón R, Hurtado MD, López R, Madejón P, Marañón T, Moreno F, Murillo JM, Nagel I. 2005. Effect of remediation on trace metal pollution in soils of the Guadiamar River Valley. In: Del Valls TA, Blasco J, eds. Integrated assessment and management of the ecosystems affected by the Aznalcóllar Mining Spill (SW, Spain). Technical Report. Cádiz: Cátedra UNESCO/Unitwin, p. 33-40.

Chapman PM. 2012. Adaptive monitoring based on ecosystem services. Sci Total Environ 415:5660.

CMA (Consejería de Medio Ambiente). 2003. The Guadiamar Green Corridor. From an ecological disaster to a newly designated natural protected area. Sevilla: RENPA, Consejería de Medio Ambiente, Junta de Andalucía.

Dickinson NM, Baker AJM, Doronila A, Laidlaw S, Reeves RD. 2009. Phytoremediation of inorganics: realism and synergies. Int J Phytoremediation 11:97-114.

Domínguez MT, Marañón T, Murillo JM, Schulin R, Robinson B. 2008. Trace element accumulation in woody plants of the Guadiamar Valley, SW Spain: A large-scale phytomanagement case study. Environ Pollut 152:50-59. 
Domínguez MT, Madejón P, Marañón T, Murillo JM. 2010a. Afforestation of a trace-element polluted area in SW Spain: woody plant performance and trace element accumulation. Eur J Forest Res 129:47-59.

Domínguez MT, Marañón T, Murillo JM, Schulin R, Robinson B. 2010b. Nutritional status of Mediterranean trees growing in a contaminated and remediated area. Water Air Soil Pollut 205:305-321.

Ernst WHO, Verkleij JAC, Schat H. 1992. Metal tolerance in plants. Acta Bot Neerl 41:229-248.

Ernst WHO, Nelissen HJM. 2000. Life cycle phases of a zinc- and cadmium-resistant ecotype of Silene vulgaris in risk assessment of polymetallic mine soils. Environ Pollut 107:329-338.

Houba VJ, Lexmond ThM, Novozamsky I, van der Lee JJ. 1996. The state of the art and future developments in soil analysis for bioavailability assessment. Sci Total Environ 178:21-28.

Kabata-Pendias A, Pendias H. 1992. Trace elements in soils and plants. Boca Raton (FL): CRC Press.

Kranner I, Colville L. 2011. Metals and seeds: biochemical and molecular implications and their significance for seed germination. Environ Exp Bot 72:93-105.

Lepp NW, Madejón P. 2007. Cadmium and Zinc in vegetation and litter of a voluntary woodland that has developed on contaminated sediment-derived soil. J Environ Qual 36:1123-1131.

Madejón P, Murillo JM, Marañón T, Cabrera F, Soriano MA. 2003. Trace element and nutrient accumulation in sunflower plants two years after the Aznalcóllar mine spill. Sci Total Environ 307:239-57.

Madejón P, Marañón T, Murillo JM, Robinson B. 2004. White poplar (Populus alba) as a biomonitor of trace elements in contaminated riparian forests. Environ Pollut 132:145-155.

Madejón P, Marañón T, Murillo JM, Robinson B. 2006. In defence of plants as biomonitors of soil quality. Environ Pollut 143:1-3.

Madejón E, Madejón P, Burgos P, Pérez de Mora A, Cabrera F. 2009. Trace elements, pH and organic matter evolution in contaminated soils under assisted natural remediation: a 4-year field study. J Hazard Mater 162:931-938.

Madejón P, Domínguez MT, Murillo JM. 2012. Pasture composition in a trace element-contaminated area: the particular case of Fe and Cd for grazing horses. Environ Monit Assess 184:20312043.

Magurran A E, Baillie SR, Buckland ST, Dick JM, Elston D, Scott E M, Smith RI, Somerfield PJ, Watt AD. 2010. Long-term datasets in biodiversity research and monitoring: assessing change in ecological communities through time. Trends Ecol Evol 25:574-582.

Marañón T, Ibáñez B, Anaya-Romero M, Muñoz-Rojas M. 2012. Estado y tendencia de los servicios de los ecosistemas forestales de Andalucía. In: Evaluación de Ecosistemas del Milenio en Andalucía. Sevilla: Consejería de Medio Ambiente, Junta de Andalucía.

Markert BA, Breure AM, Zechmeister HG. 2003. Definitions, strategies and principles for bioindication/biomonitoring of the environment. In: Markert BA, Breure AM, Zechmeister HG, editors. Bioindicators and biomonitors. Amsterdam (The Netherlands): Elsevier Science, p. 3-39.

McLaughlin MJ, Hamon RE, McLaren RG, Speir TW, Rogers SL. 2000. Review: A bioavailabilitybased rationale for controlling metal and metalloid contamination of agricultural land in Australia and New Zealand. Aus J Soil Res 38:1037-1086.

Menzies NW, Donn MJ, Kopittke PM. 2007. Evaluation of extractants for estimation of the phytoavailable trace elements in soils. Environ Pollut 145:121-130.

Mills HA, Jones BJ Jr, eds. 1996. Plant Analysis Handbook II. A Practical Sampling, Preparation, Analysis and Interpretation Guide. Athens (GA): Micromacro Publishing Inc.

Murillo JM, Marañón T, Cabrera F, López R. 1999. Accumulation of heavy metals in sunflower and sorghum plants affected by the Guadiamar spill. Sci Total Environ 242:281-292.

Perttu KL. 1993. Biomass production and nutrient removal from municipal wastes using willow vegetation filters. J Sustain Forestry 1:57-70.

Reinds GH, Posch M, de Vries W. 2009. Modelling the long-term soil response to atmospheric deposition at intensively monitored forest plots in Europe. Environ Pollut 157:1258-1269. 
Robinson BH, Mills TM, Petit D, Fung LE, Green SR, Clothier BE. 2000. Natural and induced cadmium-accumulation in poplar and willow: Implications for phytoremediation. Plant Soil 227:301-306.

Robinson BH, Green SR, Chancerel B, Mills TM, Clothier BE. 2007. Poplar for the phytomanagement of boron contaminated sites. Environ Pollut 150:225-233.

Vidal M, López-Sánchez JF, Sastre J, Jiménez G, Dagnac T, Rubio R, Rauret G. 1999. Prediction of the impact of the Aznalcóllar toxic spill on the trace element contamination of agricultural soils. Sci Total Environ 242:131-148.

Vogel-Mikuš K, Pongrac P, Kump P, Necěmer M, Simčič J, Pelicon P, Budnar M, Povh B, Regvar M. 2007. Localisation and quantification of elements within seeds of $\mathrm{Cd} / \mathrm{Zn}$ hyperaccumulator Thlaspi praecox by micro-PIXE. Environ Pollut 147:50-59.

Xiao-Lan H, Chen Y, Shenker M. 2005. Rapid whole-plant bioassay for phosphorus phytoavailability in soils. Plant Soil 271:365-376. 
Table S1. Trace element concentration in the poplar leaves along the period 1999-2010 (autumn samplings). Mean values \pm SE ( $=5$ ), expressed as $\mathrm{mg} \mathrm{kg}^{-1}$ dry matter).

\begin{tabular}{|c|c|c|c|c|c|c|c|c|c|}
\hline Site & Year & As & $\mathrm{Cd}$ & $\mathrm{Cu}$ & $\mathrm{Fe}$ & $\mathrm{Mn}$ & $\mathrm{Ni}$ & $\mathrm{Pb}$ & $\mathrm{Zn}$ \\
\hline \multirow[t]{5}{*}{$\mathrm{AZ}$} & 1999 & $3.05 \pm 0.21$ & $3.53 \pm 0.22$ & $8.39 \pm 0.37$ & $325 \pm 17.4$ & $79.9 \pm 10.2$ & $1.52 \pm 0.09$ & $5.00 \pm 0.47$ & $441 \pm 40$ \\
\hline & 2000 & $1.64 \pm 0.14$ & $2.91 \pm 0.37$ & $6.41 \pm 0.37$ & $259 \pm 12.3$ & $64.7 \pm 9.95$ & $0.74 \pm 0.07$ & $2.91 \pm 0.21$ & $409 \pm 64$ \\
\hline & 2001 & $1.13 \pm 0.14$ & $3.65 \pm 0.84$ & $9.37 \pm 0.77$ & $293 \pm 35.4$ & $87.8 \pm 15.2$ & $1.34 \pm 0.11$ & $1.60 \pm 0.19$ & $484 \pm 93$ \\
\hline & 2005 & $0.51 \pm 0.06$ & $5.15 \pm 0.50$ & $9.15 \pm 0.85$ & $283 \pm 27.4$ & $56.6 \pm 7.84$ & $0.98 \pm 0.15$ & $1.14 \pm 0.05$ & $498 \pm 51$ \\
\hline & 2010 & $0.66 \pm 0.16$ & $3.11 \pm 0.28$ & $7.84 \pm 0.26$ & $262 \pm 14.3$ & $56.3 \pm 11.7$ & $1.51 \pm 0.11$ & $0.33 \pm 0.07$ & $283 \pm 39$ \\
\hline \multirow[t]{5}{*}{ DO } & 1999 & $2.53 \pm 0.21$ & $8.28 \pm 2.20$ & $7.56 \pm 0.44$ & $286 \pm 18.4$ & $72.5 \pm 12.1$ & $1.35 \pm 0.17$ & $5.19 \pm 0.57$ & $832 \pm 174$ \\
\hline & 2000 & $2.27 \pm 0.14$ & $5.74 \pm 1.15$ & $5.00 \pm 0.21$ & $242 \pm 9.54$ & $54.9 \pm 9.86$ & $1.00 \pm 0.10$ & $4.34 \pm 0.12$ & $523 \pm 76.0$ \\
\hline & 2001 & $1.62 \pm 0.21$ & $7.38 \pm 1.96$ & $7.60 \pm 0.16$ & $228 \pm 15.9$ & $87.1 \pm 16.3$ & $1.30 \pm 0.18$ & $1.92 \pm 0.18$ & $623 \pm 103$ \\
\hline & 2005 & $0.73 \pm 0.10$ & $8.80 \pm 2.58$ & $5.84 \pm 0.17$ & $189 \pm 24.7$ & $52.4 \pm 8.32$ & $4.58 \pm 0.19$ & $1.47 \pm 0.13$ & $827 \pm 131$ \\
\hline & 2010 & $0.95 \pm 0.06$ & $5.53 \pm 0.51$ & $8.76 \pm 1.19$ & $218 \pm 14.8$ & $94.3 \pm 25.3$ & $2.55 \pm 0.50$ & $1.15 \pm 0.06$ & $860 \pm 111$ \\
\hline
\end{tabular}


Table S2. Results of the analysis of variance (ANOVA) with the effects of year, site and their interactions on the concentration of trace elements in Populus alba leaves (NS: not significant)

\begin{tabular}{lllllllll}
\hline Factor & \multicolumn{2}{c}{ As } & \multicolumn{2}{c}{$\mathrm{Cd}$} & \multicolumn{2}{c}{$\mathrm{Pb}$} & \multicolumn{2}{c}{ Zn } \\
\cline { 2 - 9 } & $F$ & $p$ & $F$ & $p$ & $F$ & $p$ & $F$ & $p$ \\
\hline Year & 50.11 & 0.000 & 1.04 & NS & 91.82 & 0.000 & 0.94 & NS \\
Site & 11.3 & 0.002 & 17.54 & 0.000 & 12.55 & 0.001 & 22.56 & 0.000 \\
Year x site & 4.99 & 0.002 & 0.52 & NS & 1.84 & NS & 2.32 & NS \\
\hline
\end{tabular}


Table S3. Results of the analysis of variance (ANOVA) with the effects of organ, site and their interactions on the concentration of trace elements in Populus alba leaves and fruits (NS: not significant)

\begin{tabular}{lllllll}
\hline Element & \multicolumn{2}{c}{ Organ } & \multicolumn{2}{c}{ Site } & \multicolumn{2}{c}{ Organ x site } \\
\cline { 2 - 7 } & $F$ & $p$ & $F$ & $p$ & $F$ & $p$ \\
\hline $\mathrm{As}$ & 0.178 & $\mathrm{NS}$ & 0.62 & $\mathrm{NS}$ & 2.03 & $\mathrm{NS}$ \\
$\mathrm{Cd}$ & 6.57 & 0.005 & 88.02 & 0.000 & 1.56 & $\mathrm{NS}$ \\
$\mathrm{Pb}$ & 1.10 & $\mathrm{NS}$ & 1.85 & $\mathrm{NS}$ & 0.33 & $\mathrm{NS}$ \\
$\mathrm{Zn}$ & 10.23 & 0.000 & 83.14 & 0.000 & 6.35 & 0.001 \\
$\mathrm{Ca}$ & 41.71 & 0.000 & 16.39 & 0.000 & 15.28 & 0.000 \\
$\mathrm{~K}$ & 31.99 & 0.000 & 9.37 & 0.001 & 8.71 & 0.000 \\
$\mathrm{~N}$ & 225.0 & 0.000 & 45.31 & 0.000 & 13.37 & 0.000 \\
$\mathrm{Mg}$ & 3.86 & 0.034 & 1.93 & $\mathrm{NS}$ & 0.90 & $\mathrm{NS}$ \\
$\mathrm{P}$ & 18.94 & 0.000 & 25.95 & 0.000 & 4.27 & 0.008 \\
$\mathrm{~S}$ & 24.94 & 0.000 & 3.93 & 0.032 & 0.81 & $\mathrm{NS}$ \\
\hline
\end{tabular}

